\title{
TECTONIC GEOMORPHOLOGY OF ESCARPMENTS: THE CASES OF KOMPOTADES AND NEA ANCHIALOS FAULTS
}

\author{
Zovoili E., Konstantinidi E. and Koukouvelas I.K. \\ Department of Geology, Division of Physical Marine Geology and Geodynamics, University of \\ Patras, 26500 Patras, Greece, iannis@upatras.gr
}

\begin{abstract}
Most active processes on the surface imply that tectonics and geomorphology converge in a way that landscape change may be used as a tectonic signal, given that erosion and weathering have been taken into account. We selected two faults, the Kompotades and the Nea Anchialos faults in the Sperchios and South Thessaly rift zones respectively, and we performed a morphometric analysis.

This analysis comprises geomorphic indices that have been used successfully in studies of active tectonics, as the mountain front sinuosity index (Smf), stream gradient index (SL) and valley floor width to valley height ratio (Vf).

At both studied mountain fronts, the Vf index ranged between 0,4 to 1,2 , implying high uplift rates, while the $S m f \approx 1$ index revealed relatively high tectonic activity, which decreases towards the west. On the other hand, the SL index though more sensitive to non-tectonic processes, (i.e. the rock resistance, stream length) is less indicative of tectonic activity. Based on the distribution of the geomorphic indices a two-fault strand model is suggested forming the mountain front in the two examples with the range-ward fault strand to be more appropriate for Kompotades fault and the basinward fault strand for Nea Anchialos fault.
\end{abstract}

\section{INTRODUCTION}

Tectonic geomorphology is defined as the study of landforms produced by tectonic processes, or the application of geomorphic principles to the solution of tectonic problems (Keller \& Pinter 1996, Burbank \& Anderson 2001). The quantitative measurement of landscape is based on the calculation of geomorphic indices using topographic maps, aerial photographs and field work. The results of several indices can be combined in order to highlight tectonic activity and to provide an assessment of a relative degree of tectonic activity in an area (Keller \& Pinter 1996).

Quantitative measurements and the calculation of geomorphic indices has been previously tested as a valuable tool in various tectonically active areas, such as the SW USA (Bull \& McFadden 1977, Rockwell et al. 1984, Keller 1986), the pacific coast of Costa Rica (Wells et al. 1988) and the Mediterranean coast of Spain (Silva et al. 2003 and citations therein). In the late years this method has been aware of more practice at different places around the world. Although landform analysis appears to be a valuable tool in tectonic investigations encompassing geological information regarding the last few thousand to two million years, only a few references are known for Greece (i.e Koukouvelas 1998, Koukouvelas et al. 2001, Goldsworthy et al. 2002).

The neotectonic structure of central Greece is dominated by a series of large normal faults with an E-W to WNW-ESE strike (Roberts \& Jackson 1991). These faults control a series of half and asymmetric grabens. Extension has dominated the deformation of the region since at least the early Pliocene (5Ma BP) and is currently taking place at a rate of $10-20 \mathrm{~mm} \mathrm{a}^{-1}$ within central Greece (Jackson \& McKenzie 1988, Billiris et al. 1989). The majority of the large normal faults bound typically the southern sides of sedimentary basins, as is the case for Sperchios basin and the Eliki and Xylocastro faults within the Gulf of Corinth. In contrast there are large normal faults that bound 
the northern sides of the basins, as the Kapareli and the Nea Anchialos faults. Two of these faults Kompotades and Nea Anchialos are studied in this paper.

Two active faults were selected in the mainland of Greece, the Kompotades fault south of the Maliakos Gulf and the Nea Anchialos fault north of the Maliakos Gulf. Both faults are geologically located above the westernmost end of the North Anatolian Fault Zone (N.A.F.Z) and the northernmost part of active subduction (Fig. 1). The Kompotades fault was chosen because of its spectacular geomorphic expression (Eliet \& Gawthorpe 1995), while the Nea Anchialos fault was chosen because it is associated with strong earthquakes (Papazachos et al. 1983). In addition, the Kompotades fault is dipping north, while the Nea Anchialos fault is dipping south. In the present study we applied morphometric analysis at these faults, complemented with field work in order to identify the tectonic activity based on geomorphic indices and attempt to correlate different faults in terms of morphometric analysis.

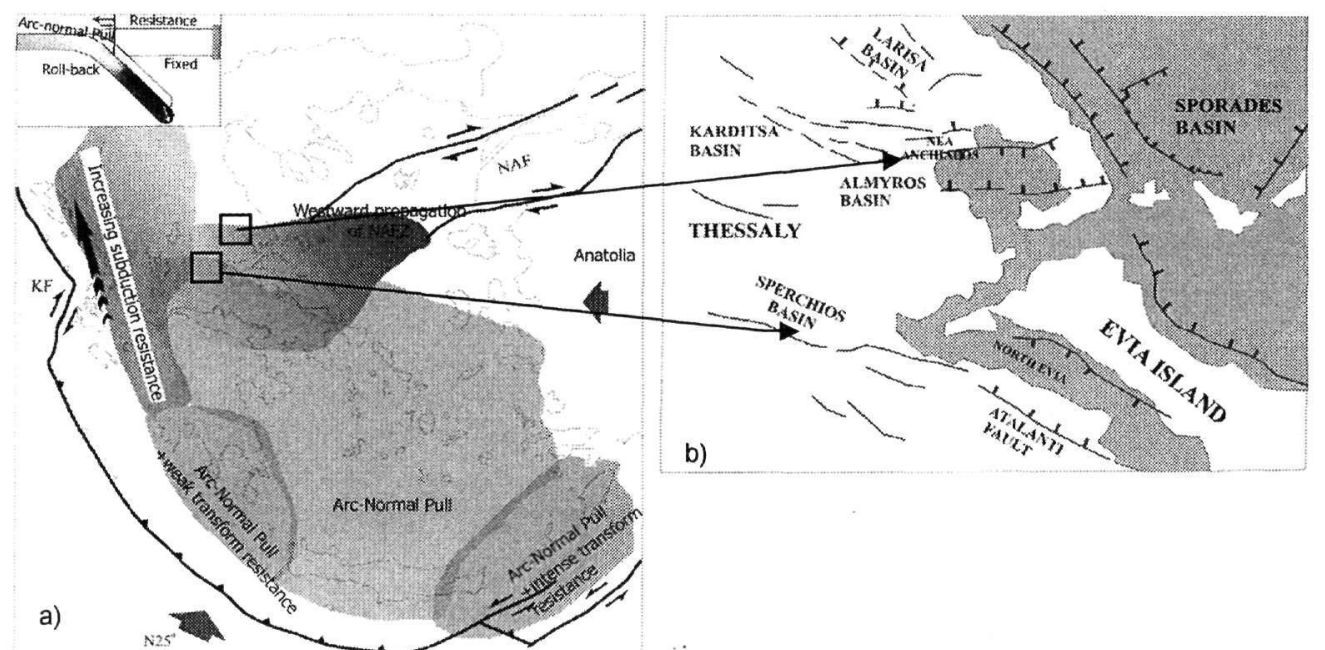

Figure 1. a) Tectonic provinces in Greece and its geodynamic setting (after Doutsos \& Kokkalas, 2001), and b) major Quaternary and Pliocene faults in the central Greece arrows show the study areas (Caputo \& Pavlides 1993, Eliet \& Gawthorpe 1995).

\section{SPERCHIOS BASIN - THE KOMPOTADES FAULT}

\section{$2.1 \quad$ Geological setting}

The Sperchios Rift in Central Greece is composed of a $100 \mathrm{Km}$ long alignment of WNW-ESE trending north- or south- facing normal faults (Roberts \& Jackson 1991, Eliet \& Gawthorpe 1995) (Fig. 2). The flanks of the Sperchios basin include pre-rift clastics, ophiolites, limestones and unconsolidated Neogene deposits (IGME 1967,1970,1989). Also Sperchios extensional basin contains huge modern fluvio-deltaic and alluvial fans (Fig. 3a).

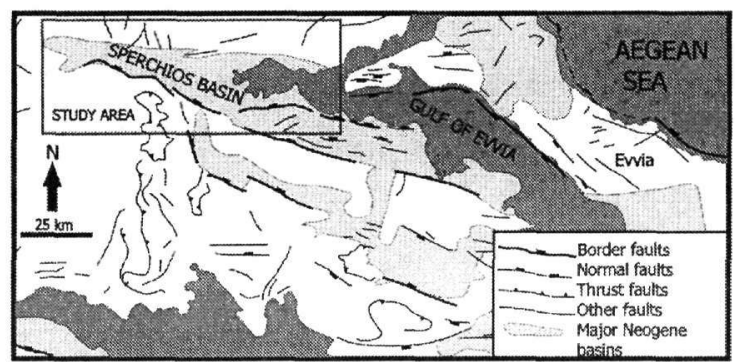

Figure 2. Simplified structural map showing major faults and basins within central Greece (Eliet \& Gawthorpe 1995). 


\section{$2.2 \quad$ Kompotades fault}

The southern flank of Sperchios basin is strongly controlled by a fault zone, called hereafter Sperchios fault zone. Limestones in the southern flank form spectacular escarpments. The fault zone is segmented on various scales, with each major fault segment being broken up into numerous component faults or fault segments (Roberts \& Gawthorpe 1994). The Kompotades fault is a 20-Km-long segment within the Sperchios fault zone which is composed by impressively exposed fault segments named as Arkitsa, Kammena Vourla, Thermopyles, Kompotades and Sperchias fault segments (Eliet \& Gawthorpe 1995).

The Kompotades fault is characterized by prominent WNW-ESE to E-W trending escarpments. It is dipping north with moderate to steep angles. Within the study area, the fault juxtaposes flysch in the west and Mesozoic limestone in the east. The hanging-wall block of the fault is accumulating fluvial deposits and alluvial fans (Fig. 3). Kompotades fault has a spectacular geomorphic expression, controlling a $2000 \mathrm{~m}$ high escarpment.
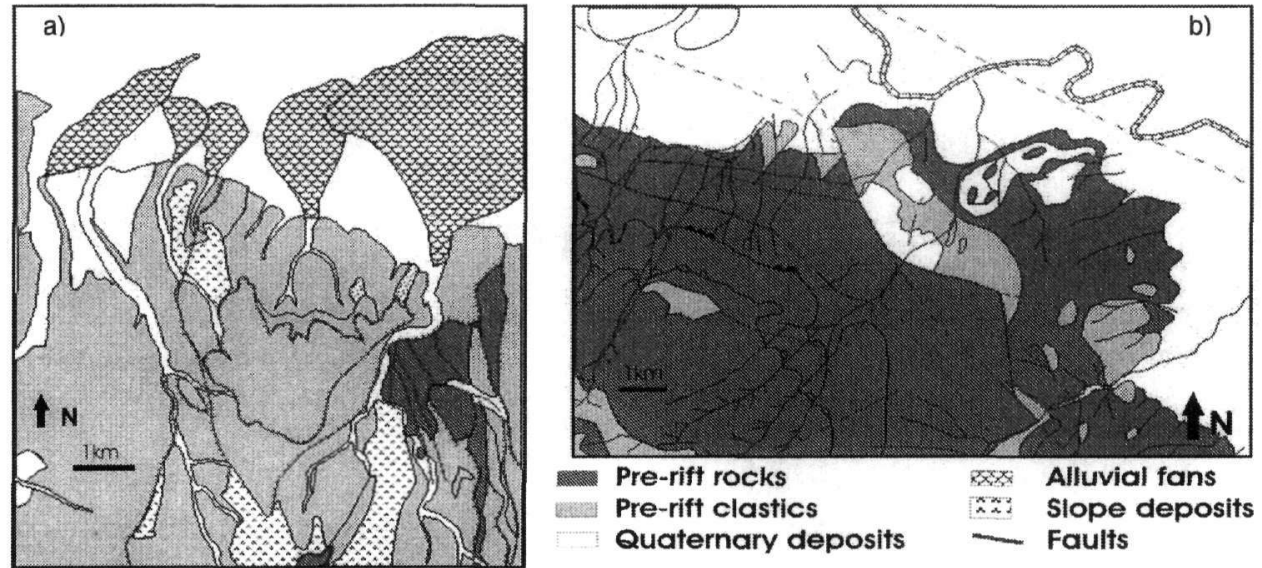

Figure 3. Simplified geological maps of the west (a) and east (b) part, of the studied area based on published geological maps (I.G.M.E, sheets Sperchias \& Lamia, 1:50000).

Faulting within the Sperchios fault zone is thought to have been active throughout the Pleistocene and earthquakes linked to fault activity have been recorded from the area near the town of Atalanti, to the east of the Sperchios rift (Roberts \& Jackson 1991). Review of historical seismicity within the broad Sperchios area shows that known strong earthquakes occurred in 426 B.C., 551 A.D., 1544, 1740, 1758, 1894 and 1916 (Ambraseys \& Jackson 1990, Ambraseys 1994, Ambraseys \& Jackson 1998, Papazachos \& Papazachou 1997), however within the area of the Kompotades fault Greek earthquake catalogs show absence of seismicity.

\section{NORTH ALMYROS BASIN - NEA ANCHIALOS FAULT}

\subsection{Geological Setting}

The 50-km-long Nea Anchialos fault, is trending from east to west and flanks the Almyros Basin to the north (Caputo 1990, Galanakis 1997, unpublished PhD). It is defined as a fault zone, which includes several E-W trending south facing fault strands. These synthetic faults are inferred to merge at a depth of about 5-10 Km into a unique fault (Papazachos et al. 1983). On good outcrops the fault plane dips $70^{\circ}$ to the south but its dip decreases with depth at $40^{\circ}$, suggesting crustal scale listric fault geometry (Papazachos et al. 1983). To the west it has a significant onshore part that is about $15-17 \mathrm{Km}$ long, while its eastward prolongation enters the Pagasitikos Gulf (Caputo 1990). The offshore segment has been detected by using offshore geophysical data and was traced eastwards from Nea Anchialos to the Cape Agistri (Perissoratis et al. 1991)(Fig. 4).

The footwall block of the fault consists of metamorphic rocks (schists, gneiss, marbles) and nonmetamorphic formations (limestones, flysch) of Paleozoic and Mesozoic age, respectively. These 
rocks belong to the Pelagonian Zone (IGME 1986) (Fig. 4). To the west there is evidence for possible intrusion of basaltic lava through the fault, dated at $1.4 \mathrm{Ma}$. The total thickness of basalts is as much as $20 \mathrm{~m}$ (Frankopoulos 1956). The hanging wall accumulates of pre-rift fluvio-lacustrine sediments of the Almyros Formation.

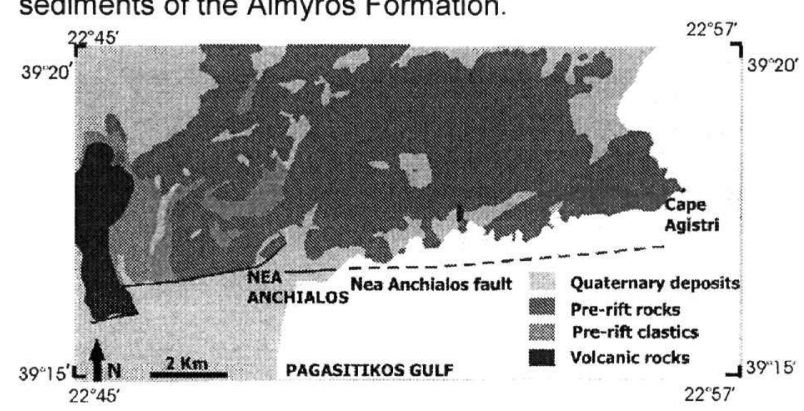

Figure 4. Simplified geological map of the studied area (I.G.M.E sheet Volos 1:50000). Thick lines show fault ruptures associated with 1980 earthquakes after Papazachos et al. 1983,

Ambraseys \& Jackson 1990, this study). Dash line show the trace of the offshore fault segment.

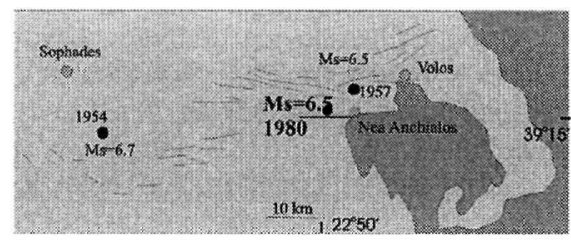

Figure 5. Map showing ruptures associated with the 1980 Nea Anchialos earthquake and historical seismicity of the broad area.

\subsection{Active deformation of the area}

There are recent and previous publications about the Nea Anchialos fault suggesting high activity (Papazachos et al. 1983, Caputo 1990, Caputo \& Pavlides 1993, Caputo 1996). In all these works it is recognized that the fault is separated into onshore and offshore fault segments. The bathymetry map of the Pagasitikos Gulf shows the direction of the offshore segment to be parallel to the shoreline between Nea Anchialos and Cape Agistri (Fig. 4). The onshore fault segment shows a geomorphic expression of about $15 \mathrm{~km}$ west of Nea Anchialos. Based on structural mapping, the westernmost end of the fault looses its clear geomorphic expression at a distance of 8 $\mathrm{km}$ west of Nea Anchialos (Fig. 4). Measurements of the fault are possible at limited outcrops, however in all cases where the fault is exposed it dips steeply to the south at about $70^{\circ}$. The presence of marine terraces near the fault trace combined with the existence of the offshore fault segment suggest probably that the fault and the north part of Almyros basin are under uplift. Of particular significance for understanding active deformation in the area is the location of the Nea Anchialos ancient harbour, which is still at sea level and is located on the interaction zone between the east and west segments of the Nea Anchialos fault. This is consistent with the mechanical principles of a step over zone with no significant overlap.

The fault appears to have hosted a strong earthquake in 1980 with a magnitude size Ms $=6,5 \mathrm{R}$ causing major damages in nearby towns and ground ruptures (Papazachos et al. 1983, Papazachos et al. 1993) (Fig. 5). According to archaeological data a strong earthquake took place between 5 th to 6 th centuries A.D. that destroyed the ancient town located at the same place with the modern one.

\section{METHODOLOGY}

Geomorphic indices have been developed as basic reconnaissance tools to identify areas experiencing rapid tectonic deformation (Bull \& McFadden 1977, Keller \& Pinter 1996). The present morphometric analysis is based on the calculation of the most commonly used geomorphic indices such as the mountain front sinuosity (Smf), the ratio of valley floor width to valley height (Vf), the stream length-gradient (SL) and the triangular facets (Pf) (Fig. 6).

The Smf index reflects the balance between erosional and tectonic forces affecting a mountain front and is defined as $S m f=L m f / L f$, where $L m f$ is the length of the mountain front and $L f$ is the straight-line length of the mountain front. Values of Smf close to 1 indicate that mountain fronts are 
associated with high tectonic activity (straight mountain front); values are increasing as the erosional processes dominate, producing more irregular mountain fronts (Bull \& McFadden 1977).

The $\mathrm{Vf}$ index is related to the shape of the valley and is calculated by the equation $\mathrm{Vf}=2 \mathrm{Vfw} /$ [(Erd-Esc) $+($ Eld-Esc)], where Vfw is the width of the valley floor, Eld \& Erd are the elevation of the left and right valley divides, respectively, and Esc is the elevation of the valley floor. Broad-floored valleys have relatively high values of $\mathrm{Vf}$ index that is associated to low uplift rates, while $\mathrm{V}$-shaped valleys have low Vf values (close to 0 ) corresponding to rapidly incising valleys (Bull \& McFadden 1977).

The stream length-gradient index is correlated to stream power and is defined as $S L=L(\Delta H / \Delta L)$, where $\mathrm{L}$ is the length of the stream from the point of interest, $\Delta \mathrm{H}$ is the change in elevation of the reach and $\Delta L$ is the length of the reach (Hack 1973). The SL index is very sensitive to changes in channel slope, to rock resistance, to topography and to the length of the stream.

Triangular facets are interpreted as variably degraded remnants of fault generated footwall scarps (Wallace 1978). In general, the apex of the triangle is the crest of the divide between dissected streams and the base corresponds to the faulted mountain front (Yeats 1997). Triangular facets of first generation (older) comprise the presence of facets away from the active mountain front while second generation facets (younger) includes facets that are near the mountain front.

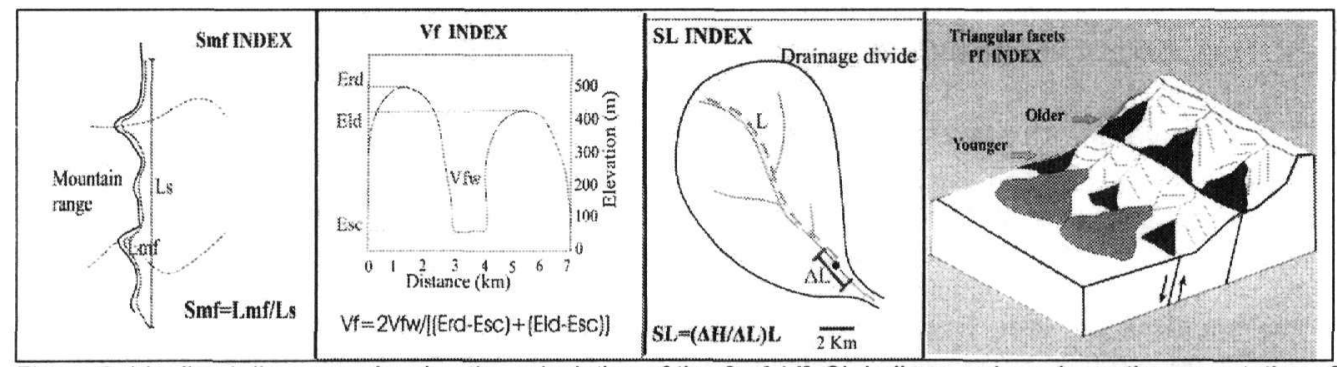

Figure 6. Idealized diagrams showing the calculation of the Smf, Vf, SL indices and a schematic presentation of faulted mountain fronts degraded into triangular facets (Keller \& Pinter 1996).

In general, the aim of morphometric analysis and the extent of a study area determine the appropriate spatial scale to be used. For example, small-scale maps (1:50000 to 1:250000) are more useful for wide areas leading to representative estimation of the Smf and SL indices. On the other hand, the Vf index is more appropriate to be calculated on larger scale maps e.g. 1:5000. Furthermore, the discrimination of a mountain front into a number of segments and the accuracy of the applied geomorphic indices is related to the chosen scale of the study area.

Morphometric analysis includes the construction of diagrams for the Vf and SL calculated values, such as frequency distribution diagrams, diagrams showing the distribution of these values along streams and along the mountain front. Usually, the Vf values are plotted with the Smf values on a same diagram in order to produce a relative degree of tectonic activity and recognition of three different classes (Bull \& McFadden 1977, Silva et al. 2003). The first class with low Vf, Smf values represents very active mountain fronts while the third class with high Vf, Smf values represents non-active fronts.

\section{DATA PRESENTATION}

The present morphometric analysis is based on the calculation of the Smf, Vf, SL and triangular facets geomorphic indices using topographic maps at scale of 1:5000. Structural mapping complemented calculation of the remaining indices. At both cases the topographic maps were digitized using Arc View 3.2 in order to produce digital elevation models (Fig. 7,8). Both total and mean calculated values of the indices were projected on diagrams. Taking into consideration the geometry defined by structural mapping of the fault and the morphology of each fault, that controlled the range front, we divided the mountain fronts into segments. 


\subsection{The Kompotades fault}

The central part of the Kompotades fault is characterized by steep slopes and is an area with prevalence of antecedent drainage pattern. For this reason it was unattainable to perform morphometric analysis and geomorphic indices. On the contrary, at the eastern and western parts, where the drainage network is controlled by faulting and lithology (Eliet \& Gawthorpe 1995), the application of geomorphic indices on a total of 30 streams was feasible. According to worldwide data long time is needed usually for base level effects to propagate upstream into the footwall block. For this reason measurements are usually made close to the range front (Burbank \& Anderson 2001). In our study the Vf index was applied for a distance of about $1 \mathrm{Km}$ away from the mountain front, while the SL values were calculated for a greater distance in order to investigate the whole area affected by the fault. On the eastern part, the mountain front is formed by one segment, while the mountain front on the western part of the fault is formed by three segments (Fig. 7).
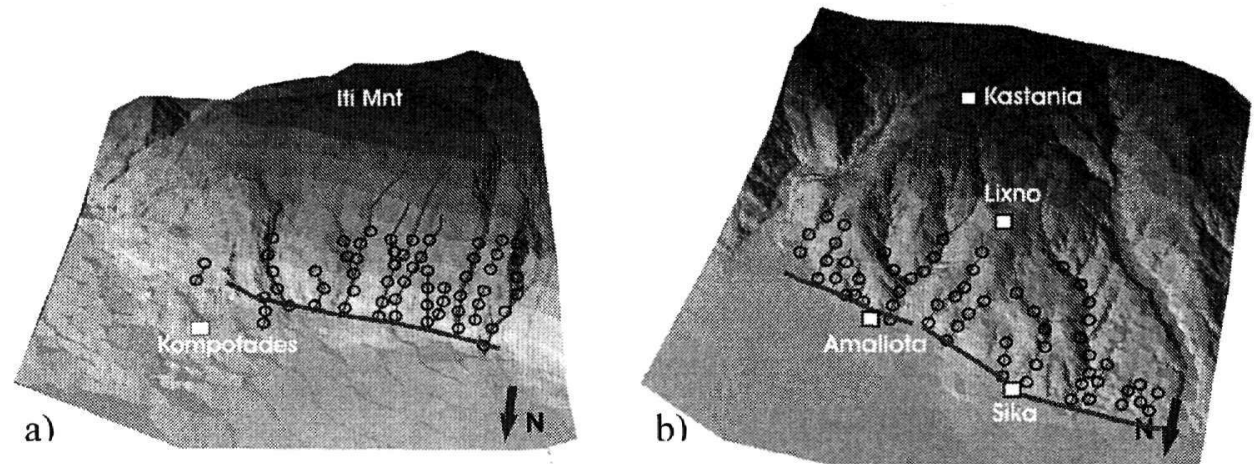

Figure 7. Digital elevation models for the east (a) and the west (b) part of the Kompotades fault. Open circles show sites where the indices applied. Lines show the trace of the faults for each mountain front.

\subsection{The Nea Anchialos fault}

The second example in this study is the west segment of the Nea Anchialos fault. The mountain front produced by the Nea Anchialos fault is separated based on its geometry and its morphology into three segments. The morphometric analysis was performed on 14 streams west of the town of Nea Anchialos (Fig. 8). The Vf values were calculated in a 1- $\mathrm{Km}$ wide zone away from the mountain front, while the $S L$ values were calculated for the whole length of the streams.

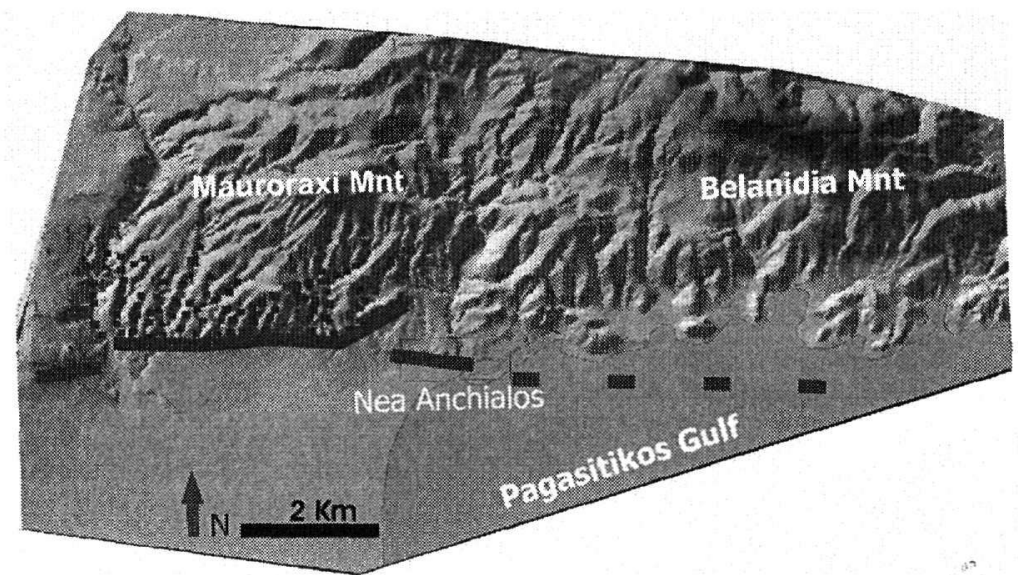

Figure 8. Digital elevation model for the Nea Anchialos fault. The diagram shows the two fault segments. On the west fault segment the three segments is recognized by the geometry and the gross morphology. The step over zone is also show note the limited overlap between the two segments. Open rectangles show sites where indices applied. 


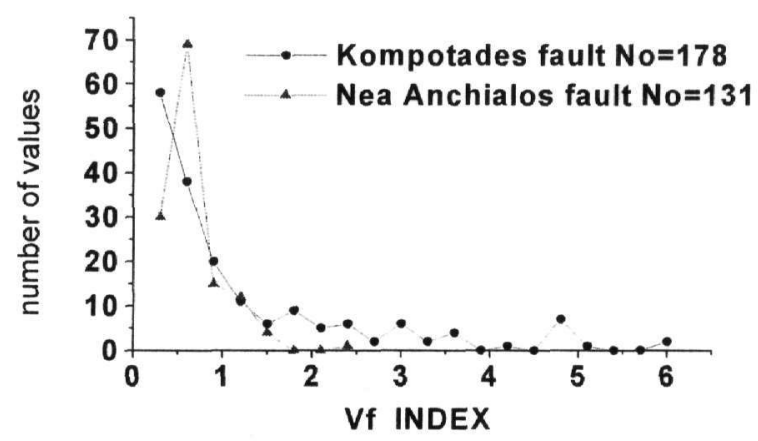

a)

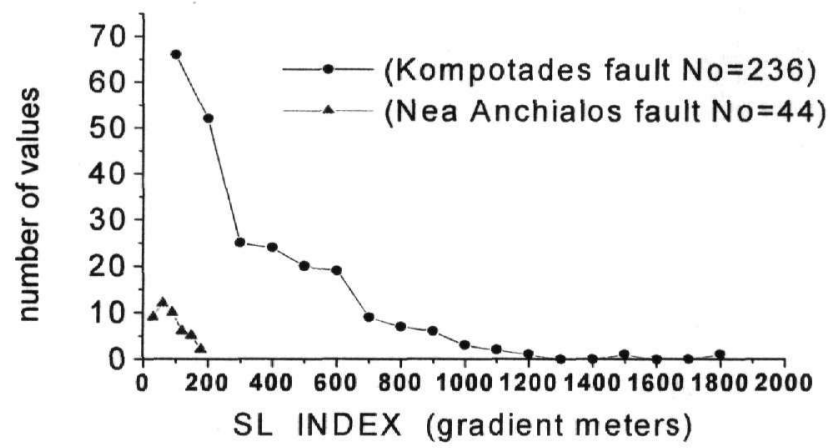

b)

Figure 9. Frequency distribution diagrams of a) Vf index and b) SL index.
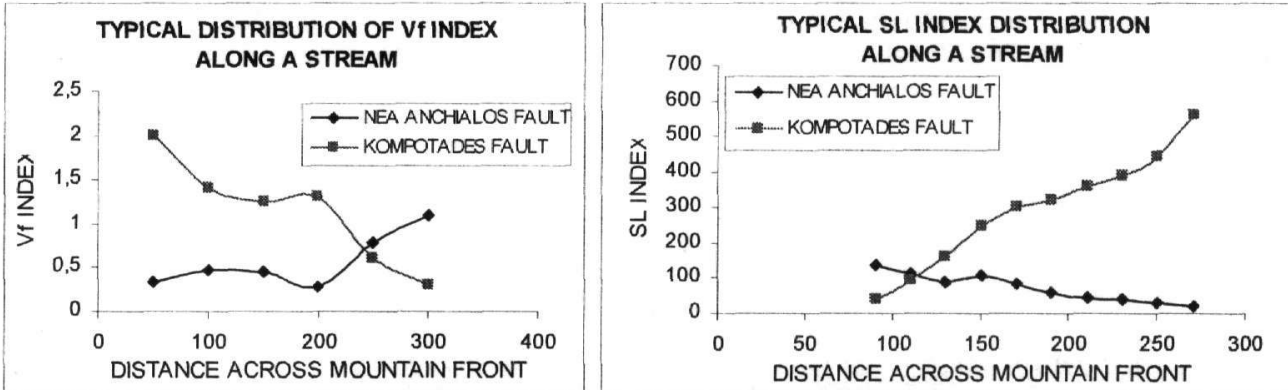

Figure 10. Typical distribution of $\mathrm{Vf}$ (left) and $\mathrm{SL}$ (right) indices along a stream.

In order to visualize our data analysis we constructed frequency distribution diagrams for the Vf and $S L$ indices. A frequency distribution diagram displays the calculated $\mathrm{Vf}$ or $\mathrm{SL}$ values on the $\mathrm{X}$ axis and the absolute number of the values on the Y-axis (Fig. 9a, 9b). Most values of the Vf index, in a total of almost 300 calculated values, ranges between 0,4 to 1,2 at both studied mountain fronts (Fig 9a), implying primarily V-shaped valleys. On the other hand, the frequency distribution diagram of the SL index (Fig. 9b) shows a significant assemblage in relatively low values at both cases. The SL values at Nea Anchialos fault remain low at almost all the studied streams while at the Kompotades fault there are relatively high values close to range front fault that diminishes rapidly. Fluctuations of SL values along streams suggest that this index is indicative of tectonic activity. In order to see the distribution of the indices along the streams crossing the fault scarp at 
high angles, both Vf and SL values were plotted on the $\mathrm{Y}$-axis with the distance from the mountain front plotted on the X-axis (Fig.10).

The distribution of the $\mathrm{Vf}$ values at the case of Kompotades fault shows a significant decrease towards the south, at a distance of $250 \mathrm{~m}$ south of the fault scarp and a significant increase of the $\mathrm{SL}$ values. On the contrary, Vf values at the case of Nea Anchialos fault increase towards the north at a distance $250 \mathrm{~m}$ north of the fault trace, while the SL values show progressive decrease (Fig. $10)$.

In addition, we plotted the Smf values for the measured segments and the mean Vf values per segment (Fig. 11). The plots suggesting higher tectonic activity where $\mathrm{Vf}$ is lower than 1 and Smf close to 1 (Bull \& McFadden 1977, Silva et al. 2003) (Fig. 12). The diagram for both faults shows that $\mathrm{Smf}$ values are lower than 1.6 and mean $\mathrm{Vf}$ values are lower than 1.2. These data are assembled in the first class of tectonic activity. In addition, for the Kompotades fault case its eastern part has lower Smf values related to its west part. The Nea Anchialos fault shows low Vf and Smf at the central part. Its western part shows higher Smf falling close to the class II of fig. 12 showing lower tectonic activity. Based on this plot we interpret as more active the east and central part of the Kompotades and Nea Anchialos faults, respectively.

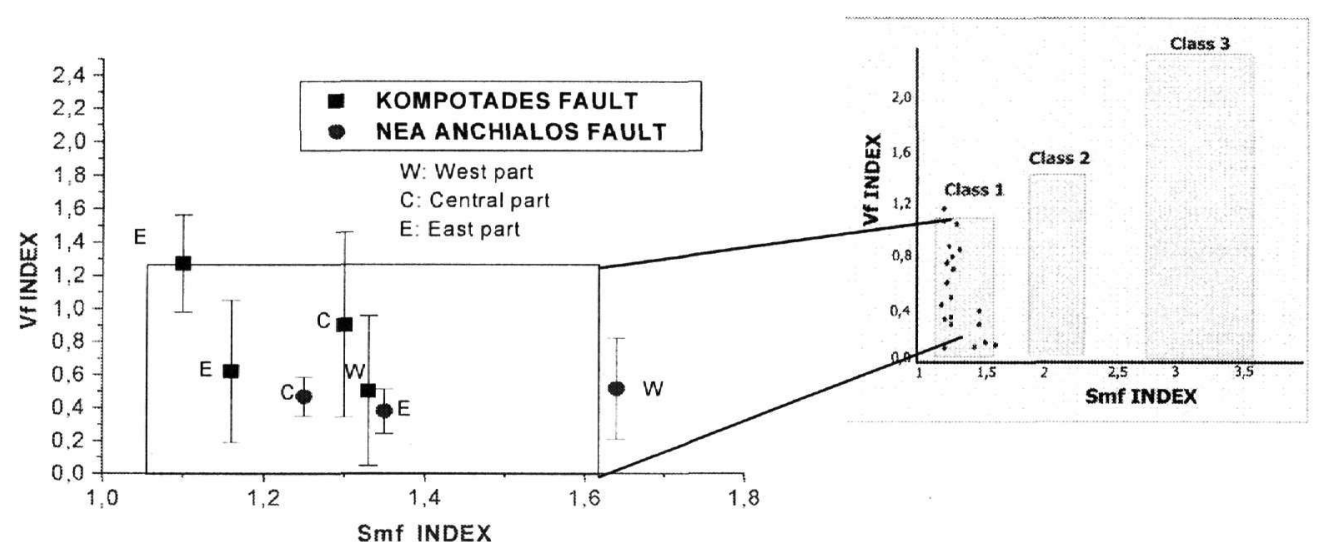

Figure 12. Smf vs Vf plot (Silva et al.

Figure 11. Smf vs Vf plot for both studied areas.

2003). Dots in the class 1 correspond to our data.

Finally, triangular facets of first generation were observed at the west part of the Kompotades fault at a distance of about $200 \mathrm{~m}$ southern of the mountain front while at the Nea Anchialos fault we recognized triangular facets of second generation at the mountain front.

\section{DISCUSSION - CONCLUSIONS}

The present study deals with application of morphometric analysis at two faults in mainland Greece, the Kompotades and the Nea Anchialos faults. Landscape analysis is based on the calculation of geomorphic indices (Smf, Vf, SL) complemented with fieldwork. Moreover, historical seismicity is a fact that should be taken into account.

At both studied faults the most significant part of the Vf values is close to 0.7 that being correlated with high uplift rates (see also Keller \& Pinter 1996). In order to attempt a correlation between Vf and recurrence interval we used historical seismicity (Papazachos \& Papazachou 1997). On the basis of historical seismicity, it appears that at the case of Nea Anchialos fault the interval is about 1500 years and for the Kompotades fault the recurrence interval is more than 2500 years. Knowing that both faults have the same Vf values and based on the recurrence interval of each fault, we suggest that Vf index appears to be sensitive for longer periods than 2500 years.

The application of the Smf, Vf and SL indices and the combination of the calculated values imply that both mountain fronts are very active (Fig.9, 10) and following Bull \& McFadden (1977) 
and Silva et al. (2003) they belong to the first class of tectonic activity (Fig.11, 12). Furthermore, the triangular facets and the distribution of the $\mathrm{Vf}$ and $\mathrm{SL}$ indices, recommend that both faults are characterized by a $250-m$-wide fault zone. Structural mapping, the distribution of the $\mathrm{Vf}$ and $\mathrm{S}_{\mathrm{L}}$ (Fig. 10 ) and the triangular facets within the two study areas suggest that within the fault zones tectonic activity is more intensive away from the mountain front in the case for the case of Kompotades fault and close to the mountain front for the Nea Anchialos fault. Based on these data we suggest a twofault strand model (Fig. 13) with the range-ward fault strand relatively more active for the Kompotades fault and the basinward fault strand more active for the Nea Anchialos fault.
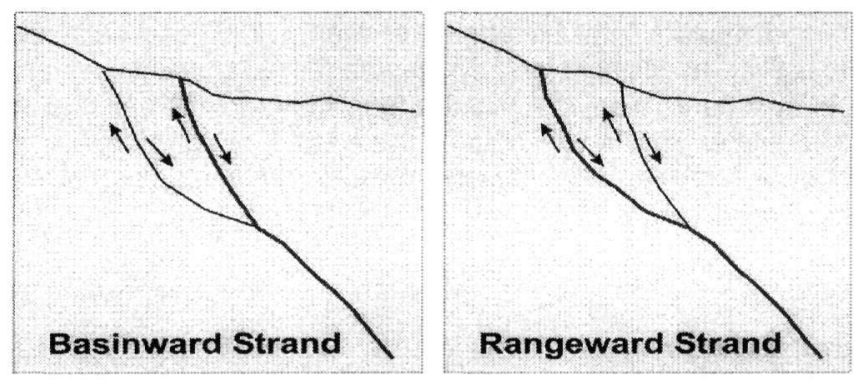

Figure 13. Two fault strand model

Finally, in both cases the westernmost end of the two faults appears to be characterized by relatively lower tectonic activity.

\section{REFERENCES}

Ambraseys N. \& Jackson J. 1990. Seismicity and associated strain of central Greece between 1890 and 1988. Geophys. J. Int., 101, p663-708.

Ambraseys N. 1994. A note on two little-known 16th-18th century earthquakes in Central Greece. Centre of north-eastern European studies-Proceedings Reports, 2, 75-82.

Ambraseys N. \& Jackson J. 1998. Faulting associated with historical and recent earthquakes in the Eastern Mediterranean region. Geophys. J. Int., 133, p390-406.

Billiris H., Paradissis D., Veis G., England P., Parsons B., Cross P., Rands P., Rayson M., Sellers P., Ashkenazi V., Davison M. \& Jackson J. 1989. Geodetic determination of the strain in Greece in the interval 1900-1988. (Abstr.) Transactions of the American Geophysical Union, 70, p719.

Bull W., \& McFadden L. 1977. Tectonic geomorphology north and south of the Garlock Fault, California, Geomorphology in Arid regions, D.O., Doehring, ed., Publications in Geomorphology, State University of New York at Bingamton, 115-138.

Burbank D.W. \& Anderson R.S. 2001. Tectonic Geomorphology. Blackwell Science.

Caputo R. 1990. Geological and structural study of the recent and active brittle deformation of the NeogeneQuaternary Basins of Thessaly (Central Greece), Ph.D. thesis, University of Florence, Sci. Ann. Aristotle University Thessaloniki, 12, vol 2, p1-252.

Caputo R., Pavlides S., 1993. Late Cenozoic geodynamic evaluation of Thessaly and surroundings (CentralNorthern Greece). Tectonophysics, 223, (3-4),p339-362.

Caputo R. 1996. The active Nea Anchialos Fault System (Central Greece): comparison of geological, morphotectonic, archaeological and seismological data, Annali di Geofisica, xxxix, n3, p557-574.

Doutsos T. \& Kokkalas S. 2001. Stress and deformation patterns in the Aegean region. Journal of Structural Geology, 23, p455-472.

Eliet P.P. \& Gawthorpe R.L. 1995. Drainage development and sediment supply within rifts, examples from the Sperchios basin, central Greece, Journal of the Geological Society, London, 152, p883-893.

Galanakis D. 1997. Neotectonic structure and stratigraphy of Neogene-Quaternary sediments of the AlmyrosPagasitikos, Pilion, Oreon-Trikeri and Maliakos basins. Unpublished PhD thesis. Thessaloniki 1997

Goldsworthy M., Jackson J. \& Haines J. 2002. The continuity of active fault systems in Greece. Geophys. J. Int., 148, p596-618.

Hack J. 1973. Stream profile analysis and stream gradient index, U. S. Geol. Surv. J. Res. 1, p421-429. Exploration, Athens

IGME 1967. Geological map, sheet Lamia, 1:50000. Institute of Geology and Mineral Exploration, Athens 
IGME 1970. Geological map, sheet Sperchias, 1:50000. Institute of Geology and Mineral

IGME 1986. Geological map, sheet Volos, 1:50000. Institute of Geology and Mineral Exploration, Athens

IGME 1989. Seismotectonic map of Greece, with seismological data. 1:500000. Institute of Geology and Mineral Exploration, Athens.

Jackson J. \& McKenzie D. 1988. Rates of active deformation in the Aegean Sea and surrounding regions. Basin Research, 1, p121-128.

Frankopoulos I.A 1956. Petrologiki meleti ton lavon tou ifaisteiou ton Thivov en Thessalia, Ph.D Thesis, University of Athens, (in Greek), p59.

Keller E. 1986. Investigation of active tectonics: use of surficial earth processes. In: Wallace, R.E. (Ed.), Active Tectonics. Studies in Geophysics. Nat. Acad. Press, Washington, DC, p136-147.

Keller E.A. \& Pinter N. 1996. Active tectonics: Earthquakes, Uplift and Landscapes. Prentice Hall, New Jersey.

Koukouvelas I.K. 1998. The Egion fault, earthquake-related and long-term deformation, Gulf of Corinth, Greece, J. Geodynamics, vol26, (2-4), p501-513.

Koukouvelas I.K., Stamatopoulos L., Katsanopoulou D. \& Pavlides S. 2001. A palaeoseismological and geoarchaeological investigation of the Eliki fault, Gulf of Corinth, Greece, Journal of Structural Geology, vol23, p531-543.

Papazachos B.C. \& Papazachou C. 1997. The earthquakes of Greece, Editions Ziti

Papazachos B.C. et al. 1983. A study of the 1980 summer seismic sequence in the Magnesia region of Central Greece, Geophysical Journal Royal Astronomical Society, 75, p155-168.

Papazachos B.C. et al. 1993. Rupture zones and active crustal deformation in Southern Thessalia, Central Greece. Boll. Geofis. Teor. Appl., 35 (139), p363-374.

Perissoratis C., Angelopoulos I., Mitropoulos D. \& Michailidis S. 1991. Surficial sediment map of the Aegean Sea Floor: Pagasitikos Sheet, scale $1: 200000$, ed. IGME, Athens.

Roberts S. \& Jackson J.A. 1991. Active normal faulting in central Greece: an overview. in The geometry of normal faults. (Eds: Roberts, A.M., Yielding, G. \& Freeman, B.), Special Publication, Geological Society of London, 56, 125-142.

Roberts G.P. \& Gawthorpe R.L. 1994. Strike variation in deformation and diagenesis along segmented normal faults: An example from the eastern Gulf of Corinth, Greece. In Lambiase, J.J. (ed.), Hydrocarbon Habitat in Rift Basins. Geological Society, London Special Publications, 80, p57-74.

Rockwell T., Keller E., Johnson D. 1984. Tectonic geomorphology of alluvial fans and mountain fronts near Ventura, California. In: Morisawa, M., Hack, T. (eds.), Tectonic Geomorphology. Publ. In Geomorphology, State University of New York, Binghamton, p183-207.

Silva P.G., Goy J.L., Zazo C. \& Bardaji T. 2003. Fault-generated mountain fronts in southeast Spain: geomorphologic assessment of tectonic and seismic activity, Geomorphplogy, vol50, p203-225.

Wells S., Bullard T., Menges T., Drake P., Karas P., Kelson K., Ritter J. \& Wesling J. 1988. Regional variations in tectonic geomorphology along segmented convergent plate boundary, Pacific Costa Rica. Geomorphology, 1, p239-265.

Yeats R.S. \& Sieh K. 1997. The geology of earthquakes, Oxford University Press. pp568. 